\title{
IDEOLOGIES OF HONORIFIC LANGUAGE
}

\author{
Judith T. Irvine
}

\section{Introduction ${ }^{1}$}

All sociolinguistic systems, presumably, provide some means of expressing respect (or disrespect); but only some systems have grammaticalized honorifics. This paper compares several languages - Javanese, Wolof, and Zulu, plus a glance at ChiBemba - with regard to honorific expressions and the social and cultural frameworks relevant thereto. ${ }^{2}$ The main question to be explored is whether one can identify any special cultural concomitants of linguistic systems in which the expression of respect is grammaticalized.

Javanese "language levels" are a classic and well-described example of a system for the expression of respect. In the sense in which I shall define "grammaticalized honorifics," Javanese provides an apt illustration. Wolof, on the other hand, does not. Of course, Javanese is only one of several Asian languages well known for honorific constructions, while Wolof, spoken in Senegal, comes from another part of the globe. But the presence or absence of honorifics is not an area characteristic of Asian languages as opposed to African languages. As we shall see, Zulu has a system of lexical alternates bearing a certain typological resemblance to the Javanese system. Moreover, many other Bantu languages (such as ChiBemba) also have grammaticalized honorifics, but in the morphology rather than in the lexicon.

Focusing on social structure instead of on geographical area, one might hypothesize that grammaticalized honorifics occur where there are royal courts (Wenger 1982) and in societies whose traditions emphasize social rank and precedence. Honorifics would be a linguistic means of expressing conventionalized differences of rank. The languages I shall compare will make it evident, however, that a hypothesis causally linking honorifics with court life or with entrenched class differences cannot be

${ }^{1}$ An earlier version of this paper was presented at a session on "Language Ideology" at the 1991 annual meeting of the American Anthropological Association. Thanks are due to Bambi Schieffelin, Paul Kroskrity, Kathryn Woolard, and Debra Spitulnik for their helpful comments.

2 The discussion of Wolof in this paper draws on my fieldwork in Senegal, mainly in the 1970's. I am grateful for the support of the National Institute of Mental Health, the National Science Foundation, and Brandeis University. ChiBemba citations come from elicitation sessions with ChiBemba speakers at Brandeis University. 
adequate. While some such link may hold true for Javanese, it does not for the other systems. The Wolof had royal courts until the French conquest a century ago, and retain (especially in rural areas) a social system structured on inequalities of birth and family origin - inequalities so marked that the ethnographic literature on the region usually describes them as caste differences. Neither in preconquest times nor today, however, is there any indication of grammatical honorifics in the Wolof language, although there were and are other ways to express deference. Zulu society, even at the height of the Zulu state, was somewhat less stratified than Wolof society (to say nothing of Java), and the Bemba polity was less strongly centralized than any of the other cases; yet both Zulu and ChiBemba have honorifics. Courts and social stratification are not irrelevant to honorific language, but they do not predict honorifics' grammaticalization.

In exploring these sociolinguistic systems I do not believe any simple correlation between forms of "on-the-ground" social structure (such as the existence of a royal court) and forms of talk (such as honorifics) is likely to be found. Instead, as I have argued elsewhere (Irvine 1985, 1989), the relationship between the distributions of social and linguistic forms is more productively sought in cultural ideologies of language - those complex systems of ideas and interests through which people interpret linguistic behaviors. In this paper, therefore, I shall pay special attention to the linguistic ideologies that link ideas about language with ideas about social rank, respect, and appropriate conduct - including the native metapragmatic terminology and theories that articulate and rationalize perceptions of language structure and use (see Silverstein 1979). I draw on a concept of ideology, rather than merely a "culture of language," because "ideology," whatever else it may mean, suggests a connection with power relations and interests that are fairly central to a social order. Some such connection is surely relevant to honorific language.

As Silverstein (1979) points out, linguistic ideology must be clearly distinguished from linguistic structures and from the distribution of uses. It is this distinction that makes the present comparison possible and, further, sheds light on these systems' historical dynamics, as I shall briefly observe.

\section{Linguistic structures}

To say that honorifics are grammaticalized in a particular language is to say that expressions of deference, or of differential status-marking, are incorporated into the language's grammatical rules (rules which include its lexicon). Thus a system of grammatical honorifics is a system of alternate linguistic expressions which are isosemantic: having the same reference-and-predication values, they differ only in their pragmatic values (expressing degrees of deference, respect, or distance). That pragmatic value operates as part of sentence-meaning, not utterance-meaning. That is, in honorifics, deference is incorporated in the construction of the sentence per se, rather than depending upon how the sentence is deployed in its social or discourse context. (Note that the possibility of regular, sarcastic uses of honorifics depends on this condition.) In Javanese, respectful expression operates through a system of lexical 
alternates. In the sentence in (1), taken from Errington (1988), each word has a set of alternates, whose combinations define a system of six "levels" of speech style: ${ }^{3}$

(1) Javanese "language levels" (Errington 1988: 90-91):

$\begin{array}{lllll}\text { KRAMA: } & \begin{array}{l}\text { 1. menapa } \\ \text { 2. menapa }\end{array} & \begin{array}{l}\text { nandalem } \\ \text { panjenengan }\end{array} & \begin{array}{l}\text { mundhut } \\ \text { mendhet }\end{array} & \begin{array}{l}\text { sekul semanten } \\ \text { sekul semanten }\end{array} \\ \text { MADYA: } & \begin{array}{l}\text { 3. napa } \\ \text { 4. napa }\end{array} & \begin{array}{l}\text { sampeyan } \\ \text { sampeyan }\end{array} & \begin{array}{l}\text { mendhet } \\ \text { njupuk }\end{array} & \text { sekul semonten } \\ & \text { 4ega semonten }\end{array}$

\begin{tabular}{|c|c|c|}
\hline$O$ & $\begin{array}{l}\text { 5. apa } \\
\text { 6. apa }\end{array}$ & $\begin{array}{l}\text { sliramu } \\
\text { kowe }\end{array}$ \\
\hline
\end{tabular}

Gloss: Question 'you' 'take' 'rice' 'that much' marker

'Did you take that much rice?'

Though rarely exhibiting the complexity and elaboration of the Javanese language levels, systems of honorific lexical alternates - respect vocabularies - are also to be found in many other languages. Among such languages are Zulu and its closest relatives, the other Nguni languages (Xhosa and Seswati). In Zulu and Xhosa the respect vocabulary is known as hlonipha. A few examples are given in (2):

(2) Zulu hlonipha vocabulary (Doke \& Vilakazi 1958):

\begin{tabular}{|c|c|c|}
\hline & ORDINARY & HLONIPHA \\
\hline 'graze; weave' & aluka & acuka \\
\hline 'be dejected' & jaba & $g x a b a$ \\
\hline 'affair' & ind $a b a$ & injušo \\
\hline 'my father' & $u b a b a$ & utsatsa \\
\hline 'hippopotamus' & imvuвu & incu $B u$ \\
\hline 'lion' & imbube & injube \\
\hline 'house' & indlu & incumba \\
\hline 'our' & $-i t h u$ & $-i t s u$ \\
\hline 'thy' & $-k h o$ & $-t o$ \\
\hline
\end{tabular}

${ }^{3}$ Note that Errington (1988) does not call the language language levels "honorifics," but instead reserves that term for those lexical items expressing respect for a referent rather than an addressee - unlike some other authors who use "honorifics" for both. Although a distinction between reference and address forms is important for his analysis, I prefer the broader usage for the comparative purposes of the present paper. 


$$
\text { (c, } \mathrm{x}=\text { clicks; } 6=\text { implosive bilabial stop) }
$$

Many Bantu languages found to the northeast of the Nguni group also have respect forms, but locate them in the morphology of the noun class system rather than in a set of alternate stems. In ChiBemba (a language of Zambia), for example, there are no sound shapes exclusively reserved for honorific reference, but respect is expressed by the use of plural prefixes (or pronouns) for singular human referents, as in (3). Noun classes 1 and 2, the singular and plural classes used for most nouns referring to humans, are the main ones affected. Thus the class 2 prefix that marks plurality in (3c) marks honorific singular in (3b):

(3) ChiBemba noun prefixes, classes 1/2:

(3a) not respectful:

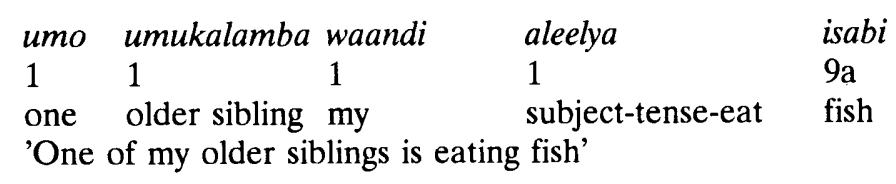

(3b) respectful:

$\begin{array}{lllll}\text { bamo } & \text { abakalamba } & \text { baandi } & \text { baleelya } & \text { isabi } \\ 2 & 2 & 2 & 2 & 9 \mathrm{a} \\ \text { one } & \text { older sibling } & \text { my } & \text { subject-tense-eat } & \text { fish } \\ \text { 'One of my older siblings is eating fish' } & \end{array}$

(3c) ambiguous:

$\begin{array}{lllll}\text { babili } & \text { abakalamba } & \text { baandi } & \text { baleelya } & \text { isabi } \\ 2 & 2 & 2 & 2 & 9 \mathrm{a} \\ \text { two } & \text { older sibling } & \text { my } & \text { subject-tense-eat } & \text { fish }\end{array}$

'Two of my older siblings are eating fish'

In its noun class system, ChiBemba also provides for various pejorative usages, by shifting the class assignment of a noun with human reference, as in (4):

(4) Chibemba honorific and pejorative noun prefixes (singular referent):

$\begin{array}{llll} & & \text { CLASS } & \text { VALUE } \\ \text { abakaši } & \text { '(respectable) wife' } & 2 & \text { honorific } \\ \text { umukasi } & \text { 'wife' } & 1 & \text { disrespectful } \\ \text { akakaši } & \text { '(insignificant) wife' } & 12 & \text { insult } \\ \text { icikaš } & \text { '(gross) wife' } & 7 & \text { insult } \\ \text { ilikaši } & \text { '(egregious [?]) wife' } & 5 & \text { "a little derogatory" }\end{array}$


All these languages thus have systems of alternate expressions differing only in pragmatic value. In all of these cases, the grammatical rules involved apply, fundamentally, to word formation (selection of stem or of prefix); the formation of sentences is affected in consequence, through concord patterns and cooccurrence constraints. Except in (3c), the pragmatic value is unambiguous and undeniable.

In contrast, Wolof does not have these kinds of rules. Speakers express respect in other ways. Although Wolof does have speech registers connoting social rank (as I have described elsewhere, Irvine 1990), the registers are constructed quite differently from, for instance, the Javanese language levels. In Javanese, each word selected from an isosemantic set has its particular pragmatic value. In Wolof, however, individual words or sentences in the two registers are not strictly isosemantic, except insofar as utterances might rely exclusively on prosodic contrasts to create register differences. As outlined in (5), these prosodic patterns, though characteristic and striking, are non-segmentable and operate more on the level of utterance meaning than of sentence meaning:

Wolof prosodic patterns:

$\begin{array}{lll} & \begin{array}{l}\text { waxu geér } \\ \text { 'Noble speech' }\end{array} & \begin{array}{l}\text { waxu gewel } \\ \text { 'Griot speech' }\end{array} \\ \text { pitch: } & \text { low } & \text { high } \\ \text { volume: } & \text { soft } & \text { loud } \\ \text { tempo: } & \text { slow } & \text { fast } \\ \text { voice: } & \text { breathy } & \text { clear } \\ \text { contour: } & \text { pitch nucleus last } & \text { pitch nucleus first } \\ \text { dynamic range: } & \text { narrow } & \text { wide }\end{array}$

Apart from their prosody, the Wolof registers depend on semantic differences and rhetorical elaboration. Pragmatic value is built up over an expanse of discourse, for the registers embody contrasting rhetorical strategies that can rarely be displayed in an individual word or a brief, decontextualized sentence.

\section{Linguistic ideologies}

Let us turn to the linguistic ideologies pertaining to three of the languages so far mentioned: Javanese, Wolof, and Zulu. How do speakers of these languages perceive these expressions of deference, and how do they theorize about them? How do they connect such expressions with ideas about respect, rank, and appropriate conduct?

For Javanese, I draw on Errington's $(1984,1988)$ elegant and complex studies of the speech of the priyayi, the traditional elite. I attempt no re-analysis of the material, other than my broader use of the term "honorifics."

The Javanese system's complexity and subtlety are evidently recognized by the speakers themselves as characterizing both the system and its highest-ranking users. 
Indeed, ideas about subtlety and refinement, on the one hand, and violence and anger on the other, seem to be crucial to the priyayi conception of their language. The "higher" (basa, especially krama) levels are considered to be governed by an ethic of proper order, peace, and calm. In them one "does not express one's own feelings" (Wolff and Poedjosoedarmo 1982: 41). The "lower" levels (ngoko) are "the language one loses one's temper in" (Errington 1984: 9). Yet, in some ways the point is not really what happens to one's own temper, but to one's addressee's. The language levels are addressee-focused; they are thought of as means of guarding addressee's equanimity, of avoiding angering the addressee, of expressing politeness by deferring to his/her wishes and effacing one's own (Errington 1988: 42-3). Polite conduct toward a respected addressee is conduct that is stylized, depersonalized, and flat-affect. Still, the use of "high," deferential styles also implies the speaker's own refinement, as shown by his/her ability to efface emotion, sensitivity to the stability of others, and pragmatic delicacy. Compare with this the linguistic ideology of rural, "traditional" Wolof. There are some quite similar ideas about rank, affectivity, and engagement with the concrete: high rank implies self-control, flat affect, the protection of others, and (especially for the religious elite) disengagement from worldly involvements. Moreover, deferential conduct toward others requires a flow of flattering words. But unlike the Javanese case, in Wolof a flow of words does not easily display any high rank or refinement on the part of their speaker.

For some insight into this difference, consider the native metapragmatic theories regarding participant roles in speaking. As example (5) has shown, the Wolof metapragmatic terminology firmly identifies the two registers, 'noble speech' and 'griot speech,' with the rank of speakers - nobles and griots being oppositely-ranked castes. It is because persons of these high and low ranks are ideologically accorded certain temperamental characteristics, such as affectivity and excitability, that the registers take the form they do. Thus 'noble speech' is flat-affect speech, while 'griot speech' is a high-affect, theatrical, hyperbolic style (see Irvine 1990).

Despite the terminology, however, the use of these registers is not limited to the social ranks they are named for. Both registers are used by almost everyone. Still, their use always conveys a sense of contrasting ranks, even if only metaphorically. Normatively, 'griot speech' is the way low-ranking griots address high-ranking nobles. Any person may employ this register to flatter an addressee; yet, in so doing, a speaker engages in griot-like, hence low-ranking, conduct.

The Wolof linguistic ideology thus identifies the register system primarily with Speaker (and Speaker's supposed temperament), only elevating Addressee by implication. The Javanese ideology, in contrast, identifies the style system primarily with Addressee, elevating Speaker only by implication (see Table 1.) Although the "implicated" participant role informs participants' strategies, the fact that the ideological focus lies elsewhere constrains what rhetorical effects are achievable, and how. 


\begin{tabular}{|c|c|c|}
\hline & SPEAKER & ADDRESSEE \\
\hline WOLOF 'griot speech' & Lowering & (Elevating) \\
\hline $\begin{array}{l}\text { JAVANESE basa (high } \\
\text { levels) }\end{array}$ & $\begin{array}{l}\text { Lowering } \\
\text { (Elevating) }\end{array}$ & Elevating \\
\hline KEY: & \multicolumn{2}{|c|}{$\begin{array}{l}\text { No parentheses: primary, focal effect } \\
\text { Parentheses: secondary, implicational effect }\end{array}$} \\
\hline
\end{tabular}

For example, Wolof nobles avoid the 'griot speech' register, and any other suggestion of low-caste conduct, in public, formal occasions. Instead, they hire a lower-ranking intermediary - usually a griot - to speak on their behalf.

The comparison of Wolof and Javanese is further illuminated, I think, by a look at a third case, Zulu, which shares some characteristics of both. Zulu has two types of deferential expression, the native terminology suggests: hlonipha 'showing respect', and $b$ onga 'praise'. These two types of expression are ideologically linked with different social contexts (family and court) and different users (women and men), respectively. Zulu married women use hlonipha words, supposedly, in order to avoid uttering the name of the husband's father - or any other word containing the radical found in his name, or sounding similar. ${ }^{4}$ If Father-in-law's name just happens to sound rather like imvu $6 u$ 'hippopotamus', the woman must call hippos incu 8 u instead. (We might think of this pattern as a sort of anti-pun.)

Hlonipha behavior applies to gesture and clothing as well as to words: to hlonipha is to avoid eye contact, restrain one's affectivity, and cover one's body in the presence of respected persons. This apparently includes using conventional euphemisms for talk about bodily functions; it certainly includes covering over, or avoiding, expressing the sounds of respected persons' names. The substitute (respectful) term may derive from a descriptive or metaphorical construction, or it may derive from patterned phonological shifts. The phonological shifts have the effect of neutralizing consonant contrasts, since the tendency is for all consonants to become [+Coronal] (especially the coronal affricates $t t^{t}$ and $j[d z z$ ) or clicks. Many hlonipha homonyms are created in this way, as illustrated in (6):

4 See Krige (1950 [1936]: 30-31), Doke 1961, Bryant 1949. Published sources on Zulu hlonipha, though including extensive lists of forms (especially Doke and Vilakazi 1958), describe the patterns of decades ago. It is not clear to me whether the Zulu respect vocabulary is still in use. Contemporary usage of hlonipha among rural Xhosa women is reported, however, in several recent papers by Finlayson $(1978,1982,1984)$. 
(6) Zulu respect homonyms (Doke and Vilakazi 1958):

ORDINARY

'swing',
'annoy' lenga

nenga

\section{HLONIPHA}

$$
\begin{aligned}
& \text { cenga } \\
& \text { cenga } \\
& (c=\text { dental click })
\end{aligned}
$$

(Uku-)B onga 'to praise', on the other hand, is to 'express gratitude' or 'worship', but in a very different way. In particular, the term identifies an exuberant, poetic style of male public oratory, usually addressed to important political figures (clan leaders, chiefs, kings, visiting dignitaries) at public gatherings. Although anyone can use this style to shout out praises and encouragement, (say) to a man engaged in a fight, or to an important man who appears on the scene, the model performers are the male professional praise-poets (izimb ongi, singular imb ongi) supported by chiefs or kings. A praise-poet may begin his training by memorizing traditional praises associated with clans and historical personages, and some of this memorized material may be included in his performance. Successful performance does not depend on exact recall of fixed text, however. On the contrary: vivid, detailed imagery, and a sense of spontaneous enthusiasm, are crucial. Interviews with prominent poets (see Opland 1983) indicate that effective praise-performance must be spontaneous, inspired, and visionary. Several poets told Opland (1983: $64 \mathrm{ff}$.) that the impulse to become a praise-performer came them originally in a dream; that their experiences are like those of a diviner who is summoned by ancestral spirits; and that the words come to them suddenly, unrehearsed and unprepared, the product of inspiration and emotional outpouring.

Zulu praise-utterance has its poeticisms, but it does not seem to have grammatical honorifics. Thus the Zulu expressive system includes an ecstatic, high-affect, engaged style without honorifics, and a flat-affect, disengaged, avoidance style with honorifics.

Now, notice that the Zulu praise-oratory style resembles, in some ways, the Wolof 'griot speech' register: both focus on praising the addressee, through dramatic, heightened-affect, semantically elaborated discourse. The resemblance is not accidental. Praise-oratory of this type is widespread in Africa; among the Wolof, it is the griots' specialty. But Wolof and Zulu differ in that the Zulu linguistic ideology does not connect praise-performance with low caste, or with particularly low rank of any sort. Speaking in $b$ onga style does not compromise the speaker's status. Notice too a typological parallel between the Zulu hlonipha style and the higher levels (termed basa) of Javanese. Both involve lowered affect, euphemism, neutralization of certain contrasts, and conspicuous conventionality. The Zulu system, then, incorporates both

${ }^{5}$ Although Opland's book concerns Xhosa praise-poetry primarily, he considers Zulu sources as well. Zulu and Xhosa praise-poetry seem virtually alike as genres, as indeed the languages are. Both systems also have hlonipha vocabularies as well, as I have already noted. 
patterns of deferential talk described earlier for Wolof and Javanese.

Comparing all three languages, Table 2 summarizes these relationships between aspects of linguistic structure and aspects of linguistic ideology, as these concern verbal conduct considered appropriate for elevating others.

\begin{tabular}{||c|l|l||}
\hline \hline \multirow{2}{*||}{ Table 2: Ideology and Structure of Other-Elevating Expressions } \\
\hline \multirow{2}{*}{ Ideology: } & PATTERN A: & PATTERN B: \\
Structure: & $\begin{array}{l}\text { Cowered-affect; } \\
\text { Semantic or sound } \\
\text { neutralization; } \\
\text { Grammatical honorifics }\end{array}$ & $\begin{array}{l}\text { Heightened-affect; } \\
\text { Spontaneity } \\
\text { Semantic or sound } \\
\text { elaboration; } \\
\text { No grammatical honorifics }\end{array}$ \\
\hline ZULU/XHOSA: & hlonipha 'respect' & B onga 'praise' \\
\hline WOLOF: & & waxu gewel 'griot speech' \\
\hline JAVANESE: & basa ('high' levels) & \\
\hline
\end{tabular}

\section{Distribution of deferential styles}

As Silverstein (1979) observes, though ideology affects speakers' strategies of language use, linguistic ideology is not the same thing as linguistic structure, and native perceptions of use are not the same as the (comparative) distribution of uses, as an outside observer might perceive them. Attempts at cross-linguistic comparison, such as the present comparison of deferential styles, are vitiated if ideology and distribution are not clearly distinguished. Were one to suppose, for Javanese, Wolof, and Zulu, that the ideological rationale for the deferential styles were also their description, the three systems might appear not to be comparable at all. For Wolof, 'noble speech' and 'griot speech' might appear to be social dialects, not registers (see Irvine 1990 for discussion); and the Zulu hlonipha vocabulary might appear to be merely a series of idiosyncratic, ephemeral constructions varying from one woman to another, rather than a systematic linguistic resource.

That is to say, the father-in-law name-avoidance rationale for Zulu hlonipha would suggest that each set of daughters-in-law would have a different respect vocabulary, depending upon the father-in-law's name; that a particular speaker's respect terms might not be very numerous; and that a term would disappear upon the daughter-in-law's death. But hlonipha usage is (or was) actually much more widespread, involving male speakers as well as female, court contexts as well as domestic, and various kinds of respected beings. From Krige (1936: 31) we learn, for example, that hlonipha forms are used by men to avoid using the name of the mother-in-law, though the custom "is not so strict" for men as it is for women. Furthermore, "the whole tribe" 
must hlonipha the name of the king or chief, while those resident at the royal court must hlonipha the names of the king's father and grandfather as well (Krige 1936: 31, 233; see also Bryant 1949). In an example conspicuously not involving a father-in-law, Bryant (1949: 220) notes, too, that "for a Zulu woman to call a porcupine by its proper name, iNgungumbane, were but to provoke it to increased depredation in her fields; therefore it must be referred to 'politely' as 'the-little-woman', or umFazazana...". The Doke and Vilakazi (1958) dictionary, which cites hundreds of hlonipha words, includes respect forms for kin terms, chiefly and royal titles, and possessive pronouns. All these forms, apparently longstanding items of Zulu vocabulary, are unlikely to be merely avoidances of a father-in-law's name. The existence of a widely-known respect vocabulary seems to be a fact of the distribution of uses, not inherent in its rationale.

The distribution of Zulu speech styles thus does not conform strictly to the linguistic ideology that links them to gender relations and domestic vs. public arenas. Nevertheless, the linguistic ideology does suggest that the primary focus and principal set of connotations for the hlonipha vocabulary lie in domestic relations, and enter the court only by extension. It is likely, in fact, that Zulu hlonipha usage antedates the rise of a strongly centralized Zulu state in the late eighteenth century. The existence of hlonipha among the Swazi and the less traditionally-centralized Xhosa implies its relative antiquity and tends to confirm the idea that the respect vocabulary arose, not in connection with the state, but in the power dynamics of Nguni family and affinal relations.

Comparing the linguistic ideology with the distribution of uses - a distinction essential for cross-linguistic studies - thus affords a glimpse of the historical dynamics of sociolinguistic systems. As Silverstein (1979) argues, the relationships among language ideology, structure, and use form a dialectical process which, in conjunction with local contingencies, induces change. For Zulu honorifics, it is worth noting in this regard that the kinds of sound changes involved in hlonipha words resemble some of the sound shifts that differentiate the Nguni language family from its Southeastern Bantu relatives, such as the shifts $6>\mathrm{t} s, \mathrm{mb}>\mathrm{nj}$, and the acquisition of click consonants. Were it possible to delve more deeply into Zulu or Xhosa ideologies of language one might be able to illuminate this process by investigating notions of sound symbolism, and attitudes toward the Khoisan languages from which the clicks were acquired.

Conceivably, then, the construction of Nguni honorific avoidance forms included the importation of "foreign" words and sounds, some of which may later have lost their specifically honorific value, being replaced by new avoidance forms. If so, this would not be the only case where honorifics have behaved like a currency in inflationary conditions. The other cases of grammatical honorifics we have examined here, Javanese and ChiBemba, both evidence processes of pragmatic devaluation. (Wolof, lacking grammatical honorifics, is not directly comparable.) Thus Errington (1988: 115) comments on Javanese terms that "have undergone pragmatic devaluation as the result of recurring patterns of strategic other-exalting, self-abasing speech style use." For ChiBemba, Richardson (1967) reports a wide extension of honorific usage in urban settings, so that some honorific address forms have tended to lose any specially 
honorific implication. Differences in honorific usage between my Bemba consultants of rural and urban origin confirm this trend and suggest that urban speakers must resort to additional means if they wish to underscore respectfulness.

To explore further the contemporary dynamics of any of these honorific systems would require recognizing, however, that language ideologies are also subject to change. Increasingly participating in a global political economy of language, these sociolinguistic systems and their ideologies are being reconfigured.

\section{Conclusions}

The comparison of these four languages suggests that grammatical honorifics accompany linguistic ideologies that specify flattened-affect, conventionality, and avoidance of engagement with the concrete or the sensory, as a way to express respect for others (rather than as a way to express one's own rank). Put another way, honorifics are embedded in an ideology in which a low-affect style can be other-elevating. They are connected with the management of affectivity and conventionality, and with the ways these relate to rank and power. What kinds of rank and power are concerned varies from one system to another. Grammatical honorifics have no necessary connection with royal courts, or with class stratification. Even where courts exist, domestic power relations may be the honorifics' primary arena.

It would not have been possible, I believe, to reach this conclusion without clearly distinguishing the distribution of forms of talk from the linguistic ideology that interprets and rationalizes them. A focus on ideology has been crucial in accounting for similarities and differences among the four cases considered in this paper; but ideology alone, without consideration of the behaviors and circumstances it interprets, would not be sufficient. To consider all of these - linguistic structures, ideologies, and distributions - facilitates the comparison of cases and helps illuminate the dynamics of historical change. In short, linguistic ideology mediates between forms of speaking and conditions of social life in a complex way.

\section{References}

Bryant, Alfred T. (1949) The Zulu people. Pietermaritzburg: Shuter and Shooter.

Doke, Clement (1961) Textbook of Zulu grammar (6th ed.). Johannesburg: Longmans.

Doke, Clement, and B. W. Vilakazi (1958) Zulu-English dictionary (2nd ed.). London: Oxford.

Errington, J. Joseph (1984) Language and social change in Java. Athens, OH: Ohio University Center for International Studies. 
Errington, J. Joseph (1988) Structure and style in Javanese. Philadelphia: University of Pennsylvania Press.

Finlayson, Rosemary (1978) "A preliminary survey of hlonipha among the Xhosa." Taalfasette 24: 48-63.

Finlayson, Rosemary (1982) "Hlonipha - the women's language of avoidance among the Xhosa." South African Journal of African Languages 1(1).

Finlayson, Rosemary (1984) "The changing nature of isihlonipho sabafazi." African Studies 43: 137-46.

Irvine, Judith T. (1985) "Status and style in language." Annual Review of Anthropology 14: 557-81.

Irvine, Judith T.(1989) "When talk isn't cheap: Language and political economy." American Ethnologist 16: 248-67.

Irvine, Judith T. (1990) "Registering affect: Heteroglossia in the linguistic expression of emotion." In C. Lutz and L. Abu-Lughod (eds.), Language and the politics of emotion. Cambridge: Cambridge University Press, 126-61.

Krige, Eileen (1950) [1936] The social system of the Zulus. Pietermaritzburg: Shuter and Shooter.

Opland, Jeff (1983) Xhosa oral poetry. Cambridge: Cambridge University Press.

Richardson, Irvine (1967) "Linguistic evolution and Bantu noun class systems." In G. Manessy and M. Houis (eds.), La classification nominale dans les langues négro-africaines. Paris: CNRS, 373-88.

Silverstein, Michael (1979) "Language structure and linguistic ideology." In P. Clyne, W. F. Hanks, and C. L. Hofbauer (eds.), The elements: A parasession on linguistic units and levels. Chicago: Chicago Linguistic Society, 193-247.

Wenger, James R. (1982) Some universals of honorific language with special reference to Japanese. Ph.D. dissertation, University of Arizona.

Wolff, J. U. and S. Poedjosoedarmo (1982) Communicative codes in central Java. Cornell University Department of Asian Studies, Southeast Asia Program, Data paper 116. 